\title{
EEG alpha phenotypes: linkage analyses and relation to alcohol dependence in an American Indian community study
}

\author{
Cindy L Ehlers ${ }^{1,2^{*}}$, lan R Gizer ${ }^{3}$, Evelyn Phillips ${ }^{1}$, Kirk C Wilhelmsen ${ }^{3,4}$
}

\begin{abstract}
Background: Evidence for a high degree of heritability of EEG alpha phenotypes has been demonstrated in twin and family studies in a number of populations. However, information on linkage of this phenotype to specific chromosome locations is still limited. This study's aims were to map loci linked to EEG alpha phenotypes and to determine if there was overlap with loci previously mapped for alcohol dependence in an American Indian community at high risk for substance dependence.

Methods: Each participant gave a blood sample and completed a structured diagnostic interview using the Semi Structured Assessment for the Genetics of Alcoholism. Bipolar EEGs were collected and spectral power determined in the alpha $(7.5-12.0 \mathrm{~Hz})$ frequency band for two composite scalp locations previously identified by principal components analyses (bilateral fronto-central and bilateral centro-parietal-occipital). Genotypes were determined for a panel of 791 micro-satellite polymorphisms in 410 members of multiplex families using SOLAR.
\end{abstract}

Results: Sixty percent of this study population had a lifetime diagnosis of alcohol dependence. Analyses of multipoint variance component LOD scores, for the EEG alpha power phenotype, revealed two loci that had a LOD score of 3.0 or above for the fronto-central scalp region on chromosomes 1 and 6 . Additionally, 4 locations were identified with LOD scores above 2.0 on chromosomes 4, 11, 14, 16 for the fronto-central location and one on chromosome 2 for the centro-parietal-occipital location.

Conclusion: These results corroborate the importance of regions on chromosome 4 and 6 highlighted in prior segregation studies in this and other populations for alcohol dependence-related phenotypes, as well as other areas that overlap with other substance dependence phenotypes identified in previous linkage studies in other populations. These studies additionally support the construct that EEG alpha recorded from fronto-central scalp areas may represent an important endophenotype associated with alcohol and other substance dependence.

\section{Background}

Although tribes differ with regard to the use of alcohol and drugs, the United States Indian Health Service has cited substance abuse as one of the most urgent health problems facing Native Americans [1-4]. It has been reported that several Native American communities have alcohol dependence rates that are 4-5 times higher than the general U.S. population [5-9]. In one American Indian community, lifetime alcohol dependence rates have been estimated at $65 \%$ in men and $54 \%$ in women

\footnotetext{
* Correspondence: cindye@scripps.edu

${ }^{1}$ From the Department of Molecular and Integrative Neurosciences, The Scripps Research Institute, 10550 North Torrey Pines Rd., SP30-1501, La Jolla, CA 92037, USA
}

[10]. Although substance dependence has been found to have a heritable component in this Indian community, specific genetic factors and the genes that encode for them have yet to be fully identified [10-16].

Electrophysiological measures are highly heritable phenotypes [17-22] that may aid in linking brain function to the processes involved in the development of substance dependence in the general population [23-25], as well as in Indian populations $[10,26,27]$. Several features of the resting EEG have been shown to be genetically influenced, and EEG phenotypes based on frequency and amplitude characteristics that may be useful in genetic analyses have been suggested [22,28,29]. EEG patterns appear to remain highly stable over most of an adult's

\section{Biomed Central}


lifespan [30], with variation within an individual studied on two different occasions being not greater than that observed between monozygotic twins [19].

Early studies investigating the variation in the EEG and its potential genetic basis focused on visually observable patterns in the EEG such as low voltage records with an absence of alpha activity or recordings with monomorphic, continuous alpha waves [30,31]. Early genetic studies identified these patterns as being highly heritable, some having an autosomal dominate mode of inheritance, and provided data in a few families for linkage to a marker on chromosome $20 \mathrm{q}$ (see $[21,30,32,33]$ for review). More recent studies, using quantitative measures, have consistently demonstrated that EEG alpha activity has perhaps the highest heritability of all the EEG frequencies, and that a moderately high to high proportion of the genetic variance in the EEG is shared among the frequency bands [34-38]. In order to further clarify the mode of genetic transmission on alpha power, Smit and colleagues [34], examined EEG alpha in a large sample of adolescent twins. Their findings confirmed high heritability for this phenotype but additionally suggested that the mode of genetic transmission was due to additive genetic factors that were largely specific. They additionally found that no significant amount of variance in EEG alpha activity could be attributed to unique environmental factors and that all non-genetic variance was most likely due to unreliability in measurement. They therefore concluded that individual differences in alpha activity, in that population, were little influenced by developmental plasticity and/or individual experiences [34].

Several important studies have begun to identify genes associated with certain EEG phenotypes. Low voltage alpha, in females, has been reported to be associated with a genetic variant that leads to low activity of the enzyme that metabolizes dopamine and norepinephrine, catechol-o-methyltransferase (COMT) [39]. Low voltage alpha has also been reported to be linked to the GABAergic system, as an association has been found between the exon 7 variant of the $\mathrm{GABA}_{\mathrm{B}}$ receptor gene and alpha voltage [40,41]. In a study of Plains Indians, a genome scan revealed evidence for linkage to EEG alpha and beta activity on chromosome 5q13-14 near the corticotropin releasing hormone binding protein $(C R H-B P)$ [27]. Additionally, in that study, an association of alpha power to $C R H-B P$ was found in Plains Indians as well as in a replication sample of 188 Caucasians [27]. These genetic findings provide evidence that EEG measures are promising endophenotypes in the search for genes involved in alcohol dependence.

In particular, several genetic studies have demonstrated that bipolar EEG measures are highly heritable [36], and may be particularly useful endophenotypes for substance dependence. Porjesz and colleagues [42] have also found significant associations between and the GABAergic system and bipolar measures of the human EEG. They found significant genetic linkage between the beta frequency of the EEG and a cluster of $G_{A B A}$ receptors genes on chromosome 4p. Additionally, a $\mathrm{GABA}_{\mathrm{A}}$ receptor gene within this cluster was found to be associated with a DSM-IV diagnosis of alcohol dependence [43].

Genetic studies of complex diseases often have advantages when they are conducted in well-defined populations such as Native American tribes living on reservations [44]. This report is part of a larger study exploring risk factors for substance dependence in an American Indian community [5,10,11,13-15,45-57]. We have previously reported that EEG alpha power is highly heritable in this American Indian community $\left(\mathrm{h}^{2}=0.62\right.$ frontal, 0.67 posterior scalp locations). The current study's aims were to: (1) map loci linked to EEG alpha phenotypes, and (2) to determine if there was overlap of the loci identified for alpha phenotypes and loci previously mapped for alcohol dependence in this American Indian community.

\section{Methods}

Participants were recruited from eight geographically contiguous reservations, with a total population of about 3,000 individuals, using a combination of a venue-based method for sampling hard-to-reach populations [58,59], as well as a respondent-driven procedure [60] as previously described $[5,13]$. The venues for recruitment included: tribal halls and culture centers, health clinics, tribal libraries, and stores on the reservations. A $10-25 \%$ rate of refusal was found depending on venue. Refusal rates were higher at tribal libraries and stores than health clinics and tribal halls/culture centers. Transportation from their home to The Scripps Research Institute was provided by the study.

To be included in the study, participants had to be an Indian indigenous to the catchment area, at least 1/16th Native American Heritage (NAH), between the age of 18 and 70 years, and be mobile enough to be transported from his or her home to The Scripps Research Institute (TSRI). Participants were excluded from electrophysiological analyses if they had a history of head trauma or were currently using medications that could bias the EEG recording. The protocol for the study was approved by the Institutional Review Board (IRB) of TSRI, and the Indian Health Council, a tribal review group overseeing health issues for the reservations where recruitment was undertaken.

Potential participants first met individually with research staff to have the study explained and give written informed consent. During a screening period, 
participants had blood pressure and pulse taken, and completed a questionnaire that was used to gather information on demographics, personal medical history, ethnicity, and drinking history [61]. Participants were asked to refrain from alcohol and drug usage for 24 hours prior to the testing. No individuals with detectable breath alcohol levels were included in the study dataset $(\mathrm{n}=3)$. During the screening period, the study coordinator also noted whether the participant was agitated, tremulous, or diaphoretic and their data were eliminated from subsequent analyses. Each participant also completed an interview with the Semi-Structured Assessment for the Genetics of Alcoholism (SSAGA) and the family history assessment module (FHAM) [62], which was used to make substance use disorder and psychiatric disorder diagnoses according to Diagnostic and Statistical Manual (DSM-III-R)[63] criteria in the probands and their family members [63]. The SSAGA is a semi- structured, poly-diagnostic psychiatric interview that has undergone both reliability and validity testing $[62,64]$. It has been used in another Native American sample $[65,66]$. Personnel from the Collaborative Study on the Genetics of Alcoholism (COGA) trained all interviewers. The SSAGA interview includes retrospective lifetime assessments of alcohol use, abuse, and dependence. A research psychiatrist/addiction specialist made all best final diagnoses.

Six channels of bipolar EEG (F3-C3, C3-P3, P3-01 and F4-C4, C4-P4, P4-02, international 10-20 system) were obtained using an electrode cap (impedance $<5 \mathrm{~K}$ ohms), as described. Bipolar recordings were obtained for comparison to previous studies in a wide range of ethnic groups [67-70]. A forehead ground electrode was used. An electrode placed left lateral infra-orbitally and referenced to the left earlobe was used to monitor both horizontal and vertical eye movement. Resting EEG was recorded in a temperature and noise controlled room while a participant was comfortably sitting on a chair. Participants were instructed to relax and keep their eyes closed, but to remain awake throughout the EEG recording. Ten to 15 minutes of EEG was collected on paper (Nihon Kohden, high-low pass filters 1-70 Hz) and also digitized for subsequent analyses. EEG records were monitored during all recordings for signs of drowsiness or artifact. Ten minutes of artifact-free, drowsiness-free EEG, as defined by Daly and Pedley [71], was computer analyzed for each channel. Muscle and movement artifact are identified by a computer driven algorithm that identifies epochs with waveforms that are between 0.25 and $0.5 \mathrm{~Hz}$ with an amplitude of higher that 100 microvolts squared per $\mathrm{Hz}$ (movement artifacts) and waveforms that are between 20 and $50 \mathrm{~Hz}$ with amplitudes above 25 microvolts squared per $\mathrm{Hz}$ (muscle artifact). These epochs are verified by the user as artifact and are then removed prior to processing. Time of recording with respect to the menstrual cycle was not controlled, as previous studies have demonstrated that the EEG variables under study are not sensitive to time during the cycle [72].

Records were digitized at $128 \mathrm{~Hz}$. The Fourier transform of consecutive four-second epochs (minimum 140) was calculated and the power spectrum produced using an IBM compatible PC with software developed by Ehlers and Havstad [73]. Power density is calculated in microvolts squared per octave, a transformation that expands amplitudes at high frequencies and reduces them at low frequencies, producing a spectrum with less $1 / \mathrm{f}$ characteristics [74]. A rectangular window is used. The transformed data were compressed into frequency bands. Mean spectral power density (microvolts squared/octave) in the alpha $7.5-12.0 \mathrm{~Hz}$ frequency band was calculated by summing the raw power spectral values within the band, multiplying by a scale factor derived from the calibration signal to produce the total power in the band in microvolts squared, and dividing by the width of the band in octaves. This width is the logarithm of the ratio of the maximum and minimum frequencies in the band, divided by the log of two. The details of the spectral analysis procedures have been previously described [50,73,74].

The data analyses were based on the overall aim that was to map loci linked to EEG alpha power phenotypes and to determine if there was overlap with loci previously mapped for alcohol dependence phenotypes in an American Indian community. To reduce the number of dependent variables in our linkage analyses, a principal component analysis (PCA) was performed over the six bipolar electrode locations for the alpha frequency band. Varimax rotation yielded two components (eigenvalues $>1$, range 2.64-2.67). The electrode sites loading on the first factor were the two fronto-central leads (F3-C3, F4-C4) and the electrode sites loading on the second factor were the four more posterior leads (C3-P3, C4-P4, P3-O1, P4-O2) (loadings ranged from 0.64 to 0.93$)$. The two orthogonal factors explained $87 \%$ of the variance. Mean power in each band was averaged across the electrode sites within each of the identified components generating a value for mean power (microvolts squared/octave) for each of the regions identified by the PCA for each participant. These values were the dependent variables in the linkage analyses.

One hundred and eighty-one pedigrees containing 1600 individuals were used in the genetic analyses. Of these, 410 individuals have both genotype and phenotype data and 236 additional individuals have only phenotypic data. Sixty-six families have only a single individual with phenotype data. These individuals were included within some analyses to the extent that they 
contribute information about trait means and variance and the impact of covariates. The family sizes for the remaining families ranged between 4 and 41 subjects (average $12.19 \pm 8.19$ ). Eighty-one families were genetically informative. The data includes 142 parent-child, 260 sibling, 53 half sibling, 11 grandparent-grandchild, 235 avuncular, and 240 cousin relative pairs. Only sibling, half-sibling, avuncular and cousin pairs were included as being potentially genetically informative. Many individuals can be linked to a few large extended pedigrees with many founders and complex "loop" structures, which were "broken" to simplify the analysis.

DNA was isolated from whole blood using an automated DNA extraction procedure, genotyping was done as previously described [75]. Genotypes were determined for a panel of 791 autosomal microsatellite polymorphisms [76] using fluorescently labeled PCR primers under conditions recommended by the manufacturer (HD5 version 2.0; Applied Biosystems, Foster City, CA). The HD5 panel set has an average marker-to-marker distance of $4.6 \mathrm{cM}$, and an average heterozygosity of greater than $77 \%$ in a Caucasian population. Allele frequencies were estimated from the entire Mission Indian population with genotype data. Gender and age accounted for greater than $5 \%$ of the phenotypic variance for each of the phenotypes. Therefore, age and gender were included as covariates in the analyses.

Genotypes were ultimately determined for 410 subjects. Samples for which less than $90 \%$ of genotypes met quality standard were repeated for the entire panel. Ultimately 273,598 genotypes were accepted. Less than $10 \%$ of the sample had the majority of the failed genotypes. All available genotypes for all of the autosomal markers were analyzed for each family using PREST [77] to detect sample and pedigree structure errors resulting in the removal of 6 individuals from further analyses. PREST assesses degree of allele sharing and calculates several statistics for each relative pair that are each sensitive difference type of pedigree miss-specification. Pedcheck was used to detect non-Mendelian inheritance patterns [78]. Relevant genotypes were reviewed blind to diagnosis. Very few Mendelian inconsistencies could be resolved by review of electropherograms. Genotypes for the nuclear family were removed for each Mendelian inconsistency. A total of 772 genotypes were removed from linkage analysis because of Mendelian inconsistencies. To further reduce errors, the probability that each genotype is correct was assessed in the context of all other available genotypes using the maximum-likelihood error-checking algorithm implemented in Merlin [79]. Genotypes that had a probability of less than 0.025 of being correct were removed from further consideration. A total of 508 genotypes were removed in this step. Duplicate genotypes were available for a large fraction of the genotype problems detected by Pedcheck and Merlin. In almost all cases these problematic results are reproducible, suggesting somatic mutations, mosaicism or "null alleles" (the failure to amplify the allele from one chromosome resulting in the assumption that an individual is homozygous for the other allele). In our previous experience about $0.5 \%$ of microsatellite genotypes using the HD5 panel give reproducible results that are inconsistent with other family genotype data.

Variance component estimate methods were used to calculate LOD scores using SOLAR v2.0.4 [80,81]. Simulation analyses were then conducted in which a genetic locus was simulated under the null hypothesis of no linkage across 50,000 trials to derive nominal p-values for the reported LOD scores [82].

\section{Results}

Four hundred and ten participants' EEG records were available for these analyses. Three hundred sixty-six (60\%) of participants met criteria for Alcohol dependence. Demographics of this sample are presented in Table 1 . There were no significant differences in the demographics between the participants with EEG records and genotyping available (e.g. the linkage sample, $n=410$ ) and the entire sample of participants in the study with valid SSAGA data $(\mathrm{n}=628)$ but no genotyping and/or EEG data.

Analyses of multipoint variance component LOD scores, for the EEG alpha phenotype, revealed two loci that had a LOD score of 3.0 or above for the frontocentral scalp region on chromosomes 1 and 6. Four additional locations were identified with LOD scores above 2.0 on chromosomes 4, 11, 14, and 16 for the fronto-central location, and one on chromosome 2 for the centro-parietal-occipital location. Figure 1 presents the linkage peaks generated by these analyses across the genome, and figure 2 presents individual chromosome data for the three largest LOD scores of chromosomes 1, 6 and 11. Table 2 presents the peak LOD scores, the closest marker location for the loci identified, empirical $p$ values, and additionally gives information of other

Table 1 Demographics

\begin{tabular}{lcc}
\hline & $\begin{array}{c}\text { Linkage Sample } \\
(\mathbf{n}=\mathbf{4 1 0})\end{array}$ & $\begin{array}{c}\text { Entire Sample } \\
(\mathbf{n}=\mathbf{6 2 8})\end{array}$ \\
\hline Gender & $\mathrm{M}=162, \mathrm{~F}=248$ & $\mathrm{M}=260, \mathrm{~F}=368$ \\
Married & 84 & 108 \\
Employed & 188 & 259 \\
Income $\geq$ \$20,000 year & 195 & 323 \\
Native American Heritage & 165 & 255 \\
$\geq 50 \%$ & & \\
Age & $30.1 \pm 0.6$ & $30.5 \pm 0.5$ \\
Education & $11.6 \pm 0.1$ & $11.6 \pm 0.1$ \\
\hline
\end{tabular}




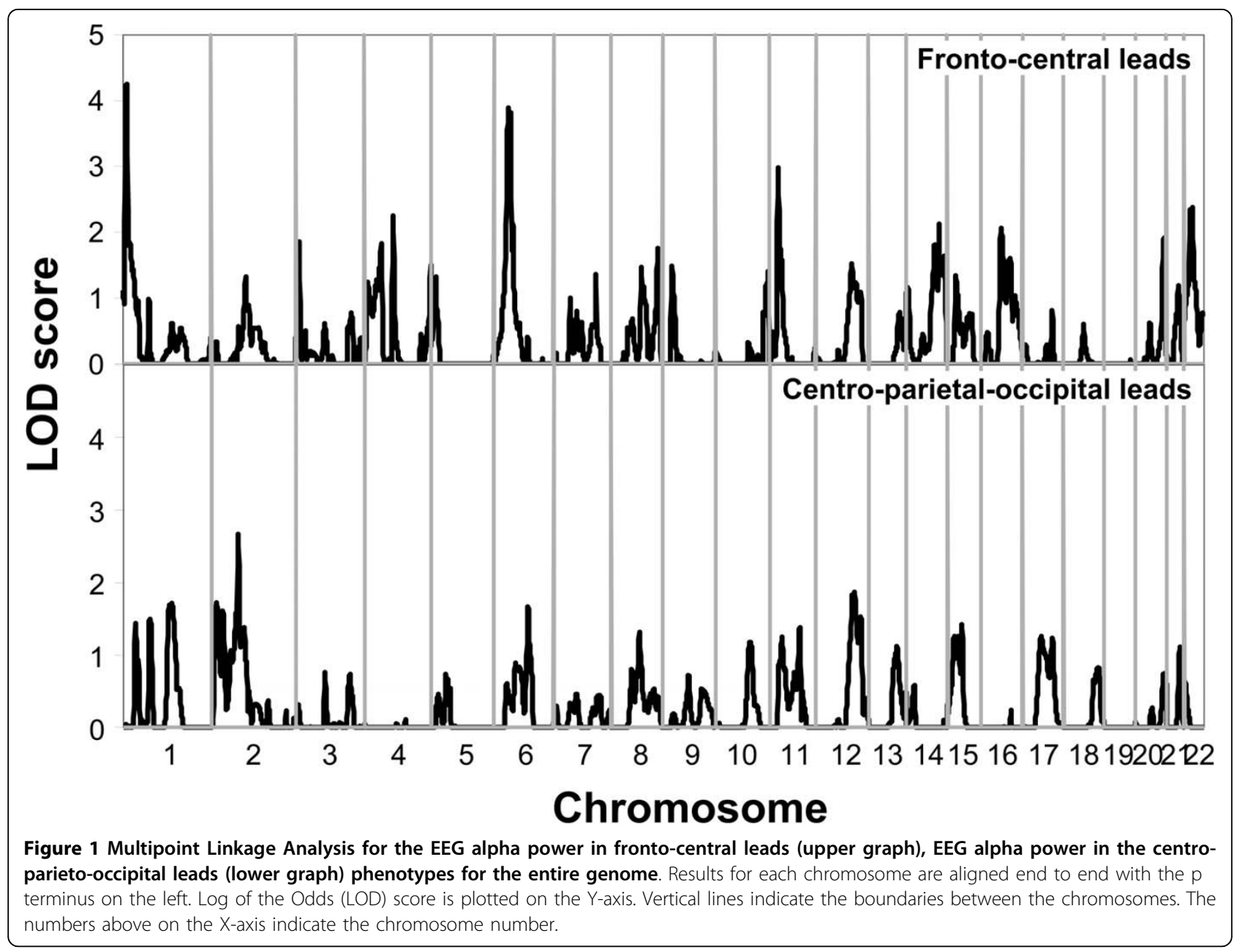

findings in the literature for substance related phenotypes observed at or near those locations.

Identified loci for EEG alpha phenotypes were found to overlap with regions of interest identified in previous genome scans for alcohol dependence related phenotypes conducted in this Indian population. The area on chromosome 4 that was identified in the present linkage analysis for frontal alpha power, was found previously for an alcohol drinking symptoms severity phenotype as well as for a "persistent smoking" phenotype in this Indian population $[13,47]$. The area on chromosome 6 that was identified in the present linkage analyses for frontal alpha power was also found previously in a genome scan for an alcohol withdrawal phenotype in this Indian population [13].

\section{Discussion}

Identifying biomarkers of alcohol dependence in Native American populations is important because of the high burden of morbidity and mortality that substance use disorders pose to some Native American groups. As reported previously, Indians in this sample have high rates of alcohol (65\% in men $54 \%$ in women) and cannabis $(32.3 \%)$ dependence and antisocial personality disorder $(9.8 \%)$, but not higher rates of major depressive disorder (8.7\%) or anxiety disorders (9.02\%) $[13,14,48,54,55]$. Our finding of high rates of DSM-III-R alcohol dependence is consistent with the findings of investigators working in several other native communities [6-9]. The identification of biomarkers that may represent endophenotypes in Indian populations may aid in genetic studies seeking to identify inherited factors that may contribute to the high rates of substance dependence in these populations.

One set of endophenotypes that may be particularly informative for the genetic analysis of substance dependence and other psychiatric disorders are human electrophysiological measures [e.g. EEG, event-related potentials (ERPs), event-related oscillations (EROs)] [83]. The EEG is a highly heritable, quantitative, biological measure that is less complex and presumably closer to gene function than diagnostic and psychological 


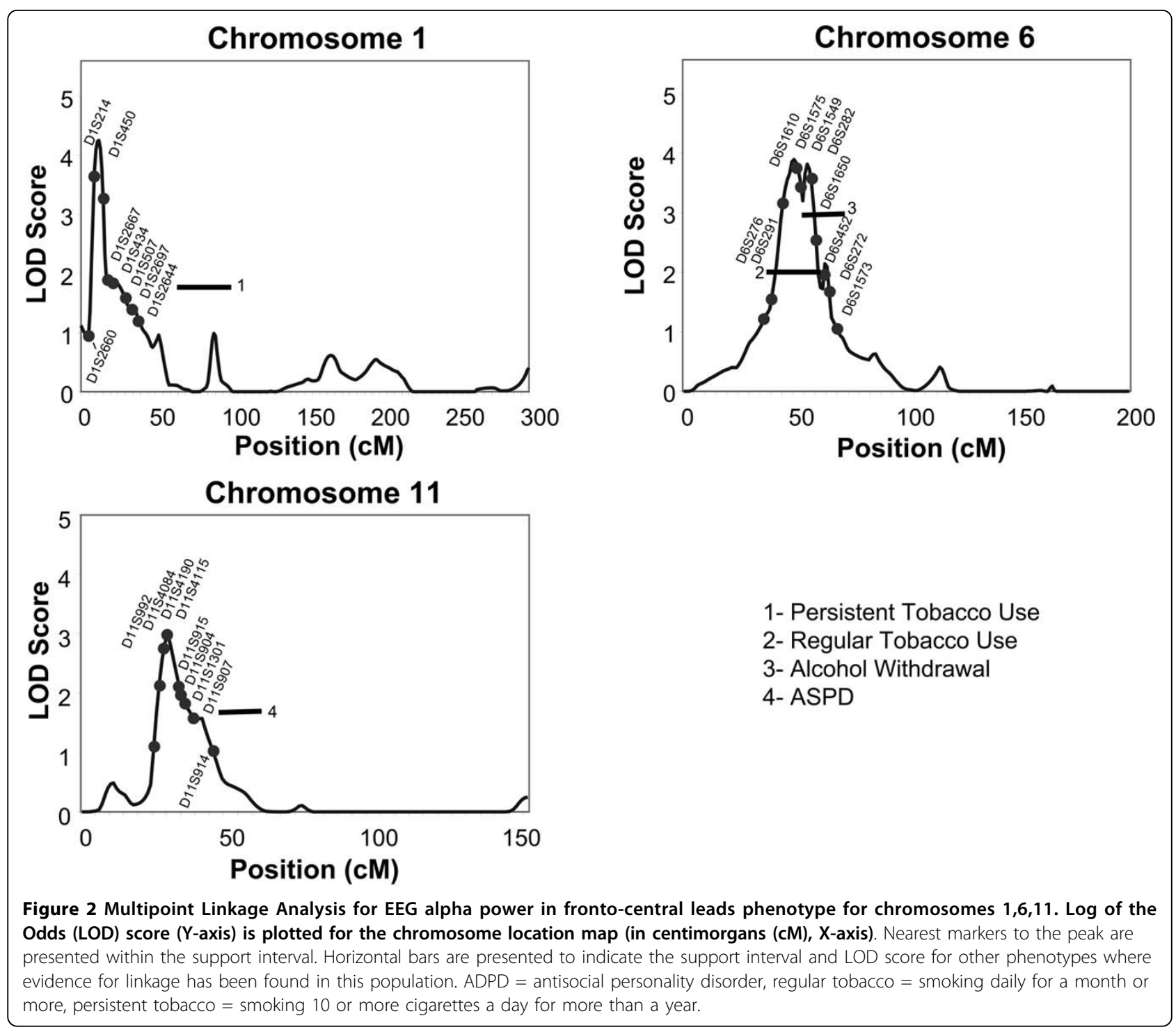

Table 2 Genetic Loci for EEG traits in an American Indian community

\begin{tabular}{|c|c|c|c|c|c|c|}
\hline CHR & Trait & $\begin{array}{l}\text { LOC } \\
\text { (cM) }\end{array}$ & LOD & $\begin{array}{l}\text { Nearest } \\
\text { Marker }\end{array}$ & $\begin{array}{l}\text { Nominal } \\
\text { p-value }\end{array}$ & Supporting References (phenotype) \\
\hline 1 & Fronto-central alpha & 12 & 4.25 & $\begin{array}{l}\text { D1S214/ } \\
\text { D1S450 }\end{array}$ & 0.00012 & Gizer et al., unpublished work (Alcohol Dep) \\
\hline 2 & $\begin{array}{l}\text { Centro-parietal- } \\
\text { occipital alpha }\end{array}$ & 92 & 2.66 & D2S286 & 0.00314 & [15] (ASPD); [85] (Alcohol Dep); [94,95] (Smoking) \\
\hline 4 & Fronto-central alpha & 98 & 2.25 & D4S2460 & 0.00318 & $\begin{array}{l}\text { [13] (Drinking/Dep symptoms); [85] (Alcohol Dep); [86] (Quant } \\
\text { Alcohol Phenotype); [87] (Max Drinks); [88,89] (Drinking) }\end{array}$ \\
\hline 6 & Fronto-central alpha & 50 & 3.90 & D6S1575 & 0.00022 & [13] (Alcohol Withdrawal); $[90,92,93]$ (Smoking); \\
\hline 11 & Fronto-central alpha & 30 & 2.98 & D11S4115 & 0.00118 & [15] (ASPD); [96] (Opioid Dep); [97] (Alcohol Dep) \\
\hline 14 & Fronto-central alpha & 113 & 2.13 & D14S65 & 0.0039 & [51,98] (Cannabis Dep); [99] (Opioid Dep); [100] (Ever Smoked) \\
\hline 16 & Fronto-central alpha & 69 & 2.07 & $\begin{array}{l}\text { D16S415/ } \\
\text { D16S3140 }\end{array}$ & 0.0051 & [101] (Ever quit smoking) \\
\hline 22 & Fronto-central alpha & 29 & 2.38 & $\begin{array}{l}\mathrm{D} 22 \mathrm{~S} 280 / \\
\mathrm{D} 22 \mathrm{~S} 277\end{array}$ & 0.00174 & $\begin{array}{l}\text { [27] (Theta EEG); [75] (LR to alcohol); [[88,103], Gizer et al., } \\
\text { unpublished work (Alcohol Dep); [102] (Smoking) }\end{array}$ \\
\hline
\end{tabular}


measures of substance dependence. We have previously reported that the heritability estimates of bipolar EEG power measures in this Indian community sample ranged from 0.16 to 0.67 [50]. These findings were comparable to that reported for the COGA sample by Tang and colleagues [36] who reported heritability estimates from 0.22 to 0.64 for bipolar EEG recordings. In both studies, the highest heritabilities were observed in the alpha and beta frequencies, particularly in posterior areas. Taken together these studies suggests that the EEG is significantly heritable in this Indian population and that heritability estimates for this population appear to be very similar to what has been found in the COGA population.

Several areas of the genome were found to have LOD scores above 2 that appear to be linked to the heritable phenotype of EEG bipolar alpha power in this Indian population. There are two loci for the alpha power phenotype, found in this Indian community study, that were identified in previously published linkage analyses for substance dependence phenotypes in this Indian population [13]. One site was on chromosome 4 at @98 $\mathrm{cM}(\mathrm{LOD}=2.25)$ near the ADH gene cluster. Bivariate linkage analysis was conducted at this site on chromosome 4 for persistent tobacco use and an alcohol drinking severity phenotype also previously identified at this site. The maximum LOD score for the bivariate analysis for this region was 3.4 [47]. This site has also been found to be linked to alcohol dependence $[84,85]$ a quantitative alcohol-related phenotype [86], and maximum number of drinks [87] in the COGA population. It has additionally been identified with alcohol drinking phenotypes in a cohort selected for smoking behavior [88] and in the Irish Affected Sib-pair study [89]. The second region identified in the present genome scan for an alpha EEG power phenotype was a region on chromosome 6 at @50 cM (LOD = 3.9) that was found previously in this Indian community sample for an alcohol withdrawal phenotype [13]. A region near this site appears to have been found to be linked to several smoking phenotypes [90-93]. The gene for the GRM4 glutamate receptor is also found in this region of chromosome 6. Thus it appears that these areas on chromosomes 4 and 6 may harbor genes for both the EEG alpha phenotype as well as a number of substance related traits observed in this Indian population as well as in other population samples.

Six other areas of the genome provided LOD scores suggesting evidence for linkage to the bipolar alpha power phenotype in this Indian population. One site was on chromosome 1 at @12 cM with a LOD score of 4.25. The same locus was previously identified in a genome scan for alcohol dependence (Gizer and colleagues, unpublished work). This site harbors a number of genes of relevance including: the GABA delta receptor gene $G A B R D$, an aldehyde dehydrogenase gene $A L D H 4 A 1$, a serotonin receptor gene $H T R 1 D$, a cannabinoid receptor gene CNR2, and a circadian rhythm gene PER3. A second site was on chromosome $2 @ 92 \mathrm{cM}(\mathrm{LOD}=2.66)$. This site is near a location (99 cM) that has been reported previously to be linked to alcohol dependence $[85,94]$ and habitual smoking [95] in the COGA sample. This site on chromosome 2 also appears to be within 10 $\mathrm{cM}$ of a site reported previously for an antisocial personality disorder phenotype in this Indian population [15]. Another site was identified on chromosome 11 for the EEG alpha power phenotype in this Indian population at @30 cM with a LOD score of 2.98. This site appears to be within $15 \mathrm{cM}$ of a site identified in a genome scan for opioid dependence in a sample of small nuclear families recruited from 4 sites [96], and also may overlap with a site identified for alcohol dependence in a SW Indian tribe [97]. Several genes of interest are found within this site including: a glycine transporter SLC6A5, brain-derived neruotrophic factor $B D N F$, and a serotonin precusor tryptophan hydroxlyase TPH1. Another site identified in the present genome scan was on chromosome 14 at @113 cM (LOD = 2.1). This site was found in two genome scans for cannabis dependence, one in this Indian population [51] and one in the COGA study [98]. This site on chromosome 14 was also found to be within $20 \mathrm{cM}$ of a site identified by Lachman and colleagues [99] for opioid dependence in a mixed racial population and for an "ever smoked" phenotype in the COGA sample [100]. On chromosome 16 a site was identified at @70 cM with a LOD score of 2.06 that was also found in a genome scan for an "ever quit smoking phenotype" [101]. The concordance between studies in identifying several loci in the genome that are associated with substance dependence phenotypes and alpha power further suggests that the search for candidate genes within these locations may be productive in identifying some general mechanisms that may underlie variation in both phenotypes.

There have been two published studies that have reported linkage findings specifically for EEG phenotypes. One study was conducted using the COGA sample [42]. In that study evidence was found for linkage and linkage disequilibrium at a $\mathrm{GABA}_{\mathrm{A}}$ receptor gene on chromosome 4 (at @56 cM) for the beta frequencies of the EEG [42]. In another genome scan, conducted in Plains American Indians, a site within $10-15 \mathrm{cM}$ of this site on chromosome 4 was also identified for theta and alpha EEG power [27]. This site was not identified in the present study. Another site identified in the study of EEG phenotypes in Plains Indians was on chromosome 5 in a region between 53 and $114 \mathrm{cM}$. This site appears to be linked to theta, alpha and beta power in the Plains 
Indian population [27]. Although this site was not identified in the present genome scan for EEG alpha phenotypes it was found in a previous genome scan for an "alcohol craving" phenotype in the present Indian population $(\mathrm{LOD}$ score $=4.5)$ [11]. One site identified in the present study on chromosome 22 at @ 29 cM (LOD = 2.4) for the alpha power phenotype was also found in the genome scan in Plains Indians for a theta EEG phenotype [27]. This general region has also been identified in genome scans for a number of other substance abuse related phenotypes such as smoking [102], alcohol dependence [[16,103], Gizer et al., unpublished work) and level of response to alcohol [75].

Interestingly 7 of the eight loci with LOD scores above 2 identified in the present study were from the frontocentral scalp location. The important of frontal cortical brain areas for a variety of impulsive behaviors including substance use disorders has been documented in a number of human and animal studies [104,105]. Disruption of orbitofrontal cortex laterality has been demonstrated in offspring from multiplex alcohol dependence families [106]. Smaller prefrontal cortices have also been shown to be associated with early-onset drinking in individuals with co-morbid mental disorders [107]. White matter microstructure deficits have also been identified several right hemisphere tracts connecting prefrontal and limbic systems in abstinent alcoholic men [108]. Taken together these studies suggest that heritable factors may contribute to some aspects of the functioning of frontal lobe areas that have been associated with substance use disorders.

\section{Conclusion}

In conclusion, two loci that had a LOD score of 3.0 or above for an EEG alpha power in fronto-central areas phenotype were found on chromosomes 1,6. Additionally, 4 loci were identified with LOD scores above 2.0 on chromosomes 4,11,14, and 16. One loci was identified on chromosome 2 for the centro-parieto-occipital region. These results corroborate the importance of regions on chromosome 4 and 6 highlighted in prior segregation studies in this and other populations for alcohol dependence-related phenotypes, as well as other areas that overlap with other substance dependence phenotypes identified in previous linkage studies in other populations. However the results of this study should be interpreted in the context of several limitations. First, the findings may not generalize to other Native Americans or represent all Indians within this population. Second, only retrospective and cross-sectional data on alcohol use disorders were assessed. Despite these limitations, this report represents an important step in an ongoing investigation to determine genetic and environmental factors associated with substance use and use disorders in this high risk and understudied ethnic group.

\section{List of Abbreviations}

CNS: Central Nervous System; COGA: Collaborative study on the genetics of alcoholism; DNA: Deoxyribonucleic Acid; DSM-III-R: Diagnostic and Statistical Manual; EEG: electroencephalogram; ERPs: event-related potentials; EROs: event-related oscillations; FHAM: family history assessment module; $\mathrm{Hz}$ : cycles/second; IRB: Institutional review board; LOD: $\log$ of the odds ratio; NAH: Native American heritage; PCA: principal component analysis; PCR: polymerase chain reaction; SSAGA: semi-structured assessment for the genetics; SOLAR: Sequential Oligogenic Linkage Analysis Routines.

\section{Acknowledgements}

This research was supported by a grant from the National Institute on Alcoholism and Alcohol Abuse grant (NIAAA) and the National Center on Minority Health and Health Disparities (NCMHD) (5R37 AA010201), the Stein Endowment fund, and by funds provided by the University of North Carolina. The authors wish to acknowledge the technical support of James Havstad, Heidi Feiler, Linda Corey, David Gilder, James Lee, Samantha Segal, Michelle Dixon, Lilach Harris, Gina Stouffer, Shirley Sanchez, Agnes Whitton and Philip Lau.

\section{Author details}

${ }^{1}$ From the Department of Molecular and Integrative Neurosciences, The Scripps Research Institute, 10550 North Torrey Pines Rd., SP30-1501, La Jolla, CA 92037, USA. ${ }^{2}$ Molecular and Experimental Medicine, The Scripps Research Institute, 10550 North Torrey Pines Rd., SP30-1501, La Jolla, CA 92037, USA. ${ }^{3}$ Department of Genetics, University of North Carolina at Chapel Hill, 120 Mason Farm Road Room 5015 Genetic Medicine Building CB 7264, Chapel Hill, NC 27599-7264, USA. ${ }^{4}$ Department of Neurology, The Carolina Center for Genome Sciences and the Bowles Center for Alcohol Studies, University of North Carolina, 4109 Neurosciences Research Bldg, CB\#7264, Chapel Hill, NC 27599-7264, USA.

\section{Authors' contributions}

Cindy $L$ Ehlers contributed to the recruitment, collection and analysis of the clinical and genetic data on the subjects. Evelyn Phillips collected all EEG data and conducted power spectral analyses. Kirk C. Wilhelmsen contributed to the genotyping. lan Gizer conducted linkage analyses. All authors contributed to writing the paper.

\section{Competing interests}

The authors declare that they have no competing interests.

Received: 8 October 2009 Accepted: 18 March 2010

Published: 18 March 2010

\section{References}

1. Burns TR: How does IHS relate administratively to the high alcoholism mortality rate?. Am Indian Alsk Native Ment Health Res 1995, 6:31-45.

2. U.S. Indian Health Service DoPS: Alcoholism: A High Priority Health Problem. Rockville, MD, U.S. Dept. of Health and Human Services, Public Health Service, Indian Health Service 1977.

3. U.S. Indian Health Service DoPS: Analysis of Fiscal Year 1981. Rockville, MD, U.S. Dept. of Health and Human Services, Public Health Service, Indian Health Service 1982.

4. U.S. Indian Health Service DoPS: Trends in Indian health. Rockville, MD, U.S Dept. of Health and Human Services, Public Health Service, Indian Health Service 1997. 
5. Gilder DA, Wall TL, Ehlers CL: Comorbidity of select anxiety and affective disorders with alcohol dependence in Southwest California Indians. Alcohol Clin Exp Res 2004, 28:1805-1813.

6. Kinzie JD, Leung PK, Boehnlein J, Matsunaga D, Johnson R, Manson S, Shore JH, Heinz J, Williams M: Psychiatric epidemiology of an Indian village: A 19-year replication study. J Nerv Ment Dis 1992, 180:33-39.

7. Kunitz SJ, Gabriel KR, Levy JE, Henderson E, Lampert K, McCloskey J, Quintero G, Russell S, Vince A: Alcohol dependence and conduct disorder among Navajo Indians. J Stud Alcohol 1999, 60:159-167.

8. Mitchell CM, Beals J, Novins DK, Spicer P: Drug use among two American Indian populations: prevalence of lifetime use and DSM-IV substance use disorders. Drug Alcohol Depend 2003, 69:29-41.

9. Robin RW, Long JC, Rasmussen JK, Albaugh B, Goldman D: Relationship of binge drinking to alcohol dependence, other psychiatric disorders, and behavioral problems in an American Indian tribe. Alcohol Clin Exp Res 1998, 22:518-523.

10. Ehlers $\mathrm{CL}$, Gilder DA, Phillips E: P3 components of the event-related potential and marijuana dependence in Southwest California Indians. Addict Biol 2008, 13:130-142.

11. Ehlers CL, Wilhelmsen KC: Genomic scan for alcohol craving in Mission Indians. Psychiatr Genet 2005, 15:71-75.

12. Ehlers $\mathrm{CL}$, Wilhelmsen $\mathrm{KC}$ : Genomic screen for loci associated with tobacco usage in Mission Indians. BMC Med Genet 2006, 7:9.

13. Ehlers $C L$, Wall $T L$, Betancourt M, Gilder DA: The clinical course of alcoholism in 243 Mission Indians. Am J Psychiatry 2004, 161:1204-1210.

14. Ehlers CL, Wall TL, Corey L, Lau P, Gilder DA, Wilhelmsen K: Heritability of illicit drug use and transition to dependence in Southwest California Indians. Psychiatr Genet 2007, 17:171-176.

15. Ehlers $\mathrm{CL}$, Gilder DA, Slutske WS, Lind PA, Wilhelmsen KC: Externalizing disorders in American Indians: Comorbidity and a genome wide linkage analysis. Am J Med Genet B Neuropsychiatr Genet 2008, 147B:690-698.

16. Wilhelmsen $K C$, Ehlers $C$ : Heritability of substance dependence in a Native American population. Psychiatr Genet 2005, 15:101-107.

17. Christian JC, Morzorati S, Norton JA Jr, Williams CJ, O'Connor S, Li TK: Genetic analysis of the resting electroencephalographic power spectrum in human twins. Psychophysiology 1996, 33:584-591.

18. Juel-Nielsen N, Harvald B: The encephalogram in uniovular twins brought up apart. Acta Genet Statistica Medica (Basel) 1958, 8:57-64

19. Lykken DT, Tellegen A, lacono WG: EEG spectra in twins: Evidence for a neglected mechanism of genetic determination. Physiol Psychol 1982, 10:60-65.

20. Stassen HH, Bomben G, Propping P: Genetic aspects of the EEG: an investigation into the within-pair similarity of monozygotic and dizygotic twins with a new method of analysis. Electroencephalogr Clin Neurophysiol 1987, 66:489-501.

21. van Beijsterveldt CE, Boomsma DI: Genetics of the human electroencephalogram (EEG) and event-related brain potentials (ERPs): a review. Hum Genet 1994, 94:319-330.

22. Vogel F: Erganzende Untersuchungen zur Genetik des menschlichen Niederspannungs-EEG. Deutsch Z Nervenheilk 1962, 185:105-111.

23. Begleiter $H$, Porjesz $B$ : What is inherited in the predisposition toward alcoholism? A proposed model. Alcohol Clin Exp Res 1999, 23:1125-1135.

24. Porjesz B, Begleiter $H$, Reich $T$, Van EP, Edenberg HJ, Foroud T, Goate A, Litke A, Chorlian DB, Stimus A, Rice J, Blangero J, Almasy L, Sorbell J, Bauer LO, Kuperman S, O'Connor SJ, Rohrbaugh J: Amplitude of visual P3 event-related potential as a phenotypic marker for a predisposition to alcoholism: preliminary results from the COGA Project. Collaborative Study on the Genetics of Alcoholism. Alcohol Clin Exp Res 1998, 22:1317-1323.

25. Porjesz B, Rangaswamy M, Kamarajan C, Jones KA, Padmanabhapillai A, Begleiter $\mathrm{H}$ : The utility of neurophysiological markers in the study of alcoholism. Clin Neuropathol 2005, 116:993-1018.

26. Criado J, Ehlers CL: Electrophysiological responses to affective stimuli in Southwest California Indians: relationship to alcohol dependence. J Stud Alcohol 2007, 68:813-823.

27. Enoch MA, Shen PH, Ducci F, Yuan Q, Liu J, White KV, Albaugh B, Hodgkinson CA, Goldman D: Common genetic origins for EEG, alcoholism and anxiety: the role of CRH-BP. PLOS ONE 2008, 3:e3620.

28. Rangaswamy M, Porjesz B, Chorlian DB, Wang $K$, Jones KA, Bauer LO, Rohrbaugh J, O'Connor SJ, Kuperman S, Reich T, Begleiter H: Beta power in the EEG of alcoholics. Biol Psychiatry 2002, 52:831-842.
29. Rangaswamy M, Porjesz B, Chorlian DB, Wang K, Jones KA, Kuperman S, Rohrbaugh J, O'Connor SJ, Bauer LO, Reich T, Begleiter H: Resting EEG in offspring of male alcoholics: beta frequencies. Int J Psychophysiol 2004, 51:239-251.

30. Vogel F: The genetic basis of the normal human electroencephalogram (EEG). Humangenetik 1970, 10:91-114.

31. Vogel F: Genetics and the electroencephalogram New York: Springer 2000.

32. Anokhin A, Steinlein O, Fischer C, Mao Y, Vogt P, Schalt E, Vogel F: A genetic study of the human low-voltage electroencephalogram. Hum Genet 1992, 90:99-112.

33. Steinlein $\mathrm{O}$, Anokhin A, Yping M, Schalt E, Vogel F: Localization of a gene for the human low-voltage EEG on $20 \mathrm{q}$ and genetic heterogeneity. Genomics 1992, 12:69-73.

34. Smit CM, Wright MJ, Hansell NK, Geffen GM, Martin NG: Genetic variation of individual alpha frequency (IAF) and alpha power in a large adolescent twin sample. Int J Psychophysiol 2006, 61:235-243.

35. Smit DJ, Posthuma D, Boomsma DI, Geus EJ: Heritability of background EEG across the power spectrum. Psychophysiology 2005, 42:691-697.

36. Tang Y, Chorlian DB, Rangaswamy M, Porjesz B, Bauer L, Kuperman S, O'Connor S, Rohrbaugh J, Schuckit M, Stimus A, Begleiter H: Genetic influences on bipolar EEG power spectra. Int I Psychophysiol 2007, 65:2-9.

37. van Baal GC, De Geus EJ, Boomsma Dl: Genetic architecture of EEG power spectra in early life. Electroencephalogr Clin Neurophysiol 1996, 98:502-514.

38. Zietsch BP, Hansen JL, Hansell NK, Geffen GM, Martin NG, Wright MJ: Common and specific genetic influences on EEG power bands delta, theta, alpha, and beta. Biol Psychol 2007, 75:154-164.

39. Enoch MA, Xu K, Ferro E, Harris CR, Goldman D: Genetic origins of anxiety in women: a role for a functional catechol-O-methyltransferase polymorphism. Psychiatr Genet 2003, 13:33-41.

40. Winterer G, Mahlberg R, Smolka MN, Samochowiec J, Ziller M, Rommelspacher HP, Herrmann WM, Schmidt LG, Sander T: Association analysis of exonic variants of the GABA(B)-receptor gene and alpha electroencephalogram voltage in normal subjects and alcoholdependent patients. Behav Genet 2003, 33:7-15.

41. Winterer G, Smolka M, Samochowiec J, Ziller M, Mahlberg R, Gallinat J, Rommelspacher HP, Herrmann WM, Sander T: Association of EEG coherence and an exonic GABA(B)R1 gene polymorphism. Am J Med Genet B Neuropsychiatr Genet 2003, 117B:51-56.

42. Porjesz B, Begleiter H, Wang K, Almasy L, Chorlian DB, Stimus AT, Kuperman S, O'Connor SJ, Rohrbaugh J, Bauer LO, Edenberg HJ, Goate A, Rice JP, Reich T: Linkage and linkage disequilibrium mapping of ERP and EEG phenotypes. Biol Psychol 2002, 61:229-248.

43. Edenberg HJ, Dick DM, Xuei X, Tian H, Almasy L, Bauer LO, Crowe RR, Goate A, Hesselbrock V, Jones K, Kwon J, Li TK, Nurnberger JI Jr, O'Connor SJ, Reich T, Rice J, Schuckit MA, Porjesz B, Foroud T, Begleiter H: Variations in GABRA2, encoding the alpha 2 subunit of the GABA(A) receptor, are associated with alcohol dependence and with brain oscillations. Am J Hum Genet 2004, 74:705-714.

44. Lander ES, Schork NJ: Genetic dissection of complex traits. Science 1994, 265:2037-2048.

45. Ehlers CL, Wilhelmsen KC: Genomic screen for substance dependence and body mass index in Southwest California Indians. Genes Brain Behav 2007, 6:184-191.

46. Ehlers $\mathrm{CL}$, Gilder DA, Wall TL, Phillips E, Feiler H, Wilhelmsen KC: Genomic screen for loci associated with alcohol dependence in Mission Indians. Am J Med Genet B Neuropsychiatr Genet 2004, 129B:110-115.

47. Ehlers CL, Slutske WS, Gilder DA, Lau P, Wilhelmsen KC: Age at first intoxication and alcohol use disorders in Southwest California Indians. Alcohol Clin Exp Res 2006, 30:1856-1865.

48. Ehlers CL, Slutske WS, Gilder DA, Lau P: Age of first marijuana use and the occurrence of marijuana use disorders in Southwest California Indians. Pharmacol Biochem Behav 2007, 86:290-296.

49. Ehlers CL, Phillips E, Finnerman G, Gilder D, Lau P, Criado J: P3 components and adolescent binge drinking in Southwest California Indians. Neurotoxicol Teratol 2007, 29:153-163.

50. Ehlers CL, Phillips E, Gizer IR, Gilder DA, Wilhelmsen KC: EEG spectral phenotypes: Heritability and association with marijuana and alcohol dependence in an American Indian community study. Drug Alcohol Depend 2009, Sep 11.

51. Ehlers $\mathrm{CL}$, Gilder DA, Gizer IR, Wilhelmsen KC: Heritability and a genomewide linkage analysis of a Type II/B cluster construct for cannabis 
dependence in an American Indian community. Addict Biol 2009, 14:338-348.

52. Garcia-Andrade C, Wall TL, Ehlers CL: Alcohol expectancies in a Native American population. Alcohol Clin Exp Res 1996, 20:1438-1442.

53. Garcia-Andrade C, Wall TL, Ehlers CL: The firewater myth and response to alcohol in Mission Indians. Am J Psychiatry 1997, 154:983-988.

54. Gilder DA, Lau P, Dixon M, Corey L, Phillips E, Ehlers CL: Co-morbidity of select anxiety, affective, and psychotic disorders with cannabis dependence in Southwest California Indians. J Addict Dis 2006, 25:67-79.

55. Gilder DA, Lau P, Corey L, Ehlers CL: Factors associated with remission from cannabis dependence in Southwest California Indians. J Addict Dis 2007, 26:23-30.

56. Gilder DA, Lau P, Ehlers CL: Item response theory analysis of age of first use of cannabis and lifetime cannabis use disorder criteria in an American Indian community sample. JSAD 2009, 70:839-849.

57. Wall $T L$, Carr $L G$, Ehlers CL: Protective association of genetic variation in alcohol dehydrogenase with alcohol dependence in Native American Mission Indians. Am J Psychiatry 2003, 160:41-46.

58. Kalton G, Anderson DW: Sampling rare populations. J Roy Stat Soc 1986, 149:65-82.

59. Muhib FB, Lin LS, Stueve A, Miller RL, Ford WL, Johnson WD, Smith PJ: A venue-based method for sampling hard-to-reach populations. Public Health Rep 2001, 116(Suppl 1):216-222.

60. Heckathorn DD: Respondent-driven sampling: a new approach to the study of hidden populations. Soc Probl 1997, 44:174-199.

61. Schuckit MA: The clinical implications of primary diagnostic groups among alcoholics. Arch Gen Psychiatry 1985, 42:1043-1049.

62. Bucholz KK, Cadoret R, Cloninger CR, Dinwiddie SH, Hesselbrock VM, Nurnberger JI Jr, Reich T, Schmidt I, Schuckit MA: A new, semi-structured psychiatric interview for use in genetic linkage studies: a report on the reliability of the SSAGA. J Stud Alcohol 1994, 55:149-158.

63. American Psychiatric Association: Diagnosis and statistical manual of mental disorders (DSM-III-R) Washington, DC: American Psychiatric Association 1987.

64. Hesselbrock M, Easton C, Bucholz KK, Schuckit M, Hesselbrock V: A validity study of the SSAGA-a comparison with the SCAN. Addiction 1999, 94:1361-1370.

65. Hesselbrock VM, Segal B, Hesselbrock MN: Alcohol dependence among Alaska Natives entering alcoholism treatment: a gender comparison. J Stud Alcohol 2000, 61:150-156.

66. Hesselbrock MN, Hesselbrock VM, Segal B, Schuckit MA, Bucholz K: Ethnicity and psychiatric comorbidity among alcohol-dependent persons who receive inpatient treatment: African Americans, Alaska Natives, Caucasians, and Hispanics. Alcohol Clin Exp Res 2003, 27:1368-1373.

67. Ehlers $C L$, Schuckit MA: EEG fast frequency activity in the sons of alcoholics. Biol Psychiatry 1990, 27:631-641.

68. Ehlers $\mathrm{CL}$, Schuckit MA: Evaluation of EEG alpha activity in sons of alcoholics. Neuropsychopharmacology 1991, 4:199-205.

69. Ehlers CL, Garcia-Andrade C, Wall TL, Cloutier D, Phillips E: Electroencephalographic responses to alcohol challenge in Native American Mission Indians. Biol Psychiatry 1999, 45:776-787.

70. Wall TL, Gallen CC, Ehlers CL: Effects of alcohol on the EEG in Asian men with genetic variations of ALDH2. Biol Psychiatry 1993, 34:91-99.

71. Daly DD, Pedley TA: Current practice of clinical electroencephalography New York, NY: Raven Press, 21990

72. Ehlers $\mathrm{CL}$, Phillips E, Parry BL: Electrophysiological findings during the menstrual cycle in women with and without late luteal phase dysphoric disorder: relationship to risk for alcoholism? Biol Psychiatry 1996, 39:720-732

73. Ehlers CL, Havstad JW: Characterization of drug effects on the EEG by power spectral time series analysis. Psychopharmacology Bull 1982, 18:43-47.

74. Ehlers $C L$, Wall $T L$, Schuckit MA: EEG spectral characteristics following ethanol administration in young men. Electroencephalogr Clin Neurophysiol 1989, 73:179-187.

75. Wilhelmsen KC, Schuckit M, Smith TL, Lee JV, Segall SK, Feiler HS, Kalmijn J: The search for genes related to a low-level response to alcohol determined by alcohol challenges. Alcohol Clin Exp Res 2003, 27:1041-1047

76. Weber JL, May PE: Abundant class of human DNA polymorphisms which can be typed using the polymerase chain reaction. Am J Hum Genet 1989, 44:388-396.
77. McPeek MS, Sun L: Statistical tests for detection of misspecified relationships by use of genome-screen data. Am J Hum Genet 2000, 66:1076-1094.

78. O'Connell JR, Weeks DE: PedCheck: a program for identification of genotype incompatibilities in linkage analysis. Am J Hum Genet 1998, 63:259-266.

79. Abecasis GR, Cherny SS, Cookson WO, Cardon LR: Merlin-rapid analysis of dense genetic maps using sparse gene flow trees. Nat Genet 2002, 30:97-101.

80. Almasy L, Blangero J: Multipoint quantitative-trait linkage analysis in general pedigrees. Am J Hum Genet 1998, 62:1198-1211.

81. Southwest Foundation for Biomedical Research (S.F.B.R): Sequential Oligogenic Linkage Analysis Routines. San Antonio, TX, Southwest Foundation for Biomedical Research 2009 [http://solar.sfbrgenetics.org/], Last accessed 02.01.10.

82. Blangero J, Williams JT, Almasy L: Robust LOD scores for variance component-based linkage analysis. Genet Epidemiol 2000, 19(Suppl 1): S8-14.

83. Begleiter $H$, Porjesz B: Genetics of human brain oscillations. Int $J$ Psychophysiol 2006, 60:162-171.

84. Corbett J, Saccone NL, Foroud T, Goate A, Edenberg H, Nurnberger J, Porjesz B, Begleiter H, Reich T, Rice JP: A sex-adjusted and age-adjusted genome screen for nested alcohol dependence diagnoses. Psychiatr Genet 2005, 15:25-30.

85. Reich T, Edenberg HJ, Goate A, Williams JT, Rice JP, van Eerdewegh $P$, Foroud T, Hesselbrock V, Schuckit MA, Bucholz K, Porjesz B, Li TK, Conneally PM, Nurnberger JI Jr, Tischfield JA, Crowe RR, Cloninger CR, Wu W, Shears S, Carr K, Crose C, Willig C, Begleiter H: Genome-wide search for genes affecting the risk for alcohol dependence. Am J Hum Genet 1998, 81:207-215.

86. Dick DM, Nurnberger J Jr, Edenberg HJ, Goate A, Crowe R, Rice J, Bucholz KK, Kramer J, Schuckit MA, Smith TL, Porjesz B, Begleiter H, Hesselbrock V, Foroud T: Suggestive linkage on chromosome 1 for a quantitative alcohol-related phenotype. Alcohol Clin Exp Res 2002, 26:1453-1460.

87. Saccone NL, Kwon JM, Corbett J, Goate A, Rochberg N, Edenberg HJ, Foroud T, Li TK, Begleiter H, Reich T, Rice JP: A genome screen of maximum number of drinks as an alcoholism phenotype. Am J Med Genet B Neuropsychiatr Genet 2000, 96B:632-637.

88. Wilhelmsen KC, Swan GE, Cheng LS, Lessov-Schlaggar CN, Amos Cl, Feiler HS, Hudmon KS, Ring HZ, Andrews JA, Tildesley E, Benowitz NL, Hops H: Support for previously identified alcoholism susceptibility loci in a cohort selected for smoking behavior. Alcohol Clin Exp Res 2005, 29:2108-2115.

89. Prescott CA, Sullivan PF, Kuo PH, Webb BT, Vittum J, Patterson DG, Thiselton DL, Myers JM, Devitt M, Halberstadt LJ, Robinson VP, Neale MC, Oord van den EJ, Walsh D, Riley BP, Kendler KS: Genomewide linkage study in the Irish affected sib pair study of alcohol dependence: evidence for a susceptibility region for symptoms of alcohol dependence on chromosome 4. Mol Psychiatry 2006, 11:603-611.

90. Duggirala R, Almasy L, Blangero J: Smoking behavior is under the influence of a major quantitative trait locus on human chromosome $5 \mathrm{q}$. Genet Epidemiol 1999, 17(Suppl 1):S139-S144.

91. Li MD: Identifying susceptibility loci for nicotine dependence: 2008 update based on recent genome-wide linkage analyses. Hum Genet 2008, 123:119-131.

92. Morley KI, Medland SE, Ferreira MA, Lynskey MT, Montgomery GW, Heath AC, Madden PA, Martin NG: A possible smoking susceptibility locus on chromosome 11p12: evidence from sex-limitation linkage analyses in a sample of Australian twin families. Behav Genet 2006, 36:87-99.

93. Vink JM, Beem AL, Posthuma D, Neale MC, Willemsen G, Kendler KS, Slagboom PE, Boomsma DI: Linkage analysis of smoking initiation and quantity in Dutch sibling pairs. Pharmacogenomics J 2004, 4:274-282

94. Foroud T, Edenberg HJ, Goate A, Rice J, Flury L, Koller DL, Bierut LJ, Conneally PM, Nurnberger Jl, Bucholz KK, Li TK, Hesselbrock V, Crowe R, Schuckit M, Porjesz B, Begleiter H, Reich T: Alcoholism susceptibility loci: confirmation studies in a replicate sample and further mapping. Alcohol Clin Exp Res 2000, 24:933-945.

95. Bierut LJ, Rice JP, Goate A, Hinrichs AL, Saccone NL, Foroud T, Edenberg HJ, Cloninger CR, Begleiter H, Conneally PM, Crowe RR, Hesselbrock V, Li TK, Nurnberger JI Jr, Porjesz B, Schuckit MA, Reich T: A genomic scan for 
habitual smoking in families of alcoholics: common and specific genetic factors in substance dependence. Am J Med Genet A 2004, 124:19-27.

96. Gelernter J, Panhuysen C, Wilcox M, Hesselbrock V, Rounsaville B, Poling J, Weiss R, Sonne S, Zhao H, Farrer L, Kranzler HR: Genomewide linkage scan for opioid dependence and related traits. Am J Hum Genet 2006, 78:759-769.

97. Long JC, Knowler WC, Hanson RL, Robin RW, Urbanek M, Moore E, Bennett PH, Goldman D: Evidence for genetic linkage to alcohol dependence on chromosomes 4 and 11 from an autosome-wide scan in an American Indian population. Am J Med Genet 1998, 81:216-221.

98. Agrawal A, Hinrichs AL, Dunn G, Bertelsen S, Dick DM, Saccone SF, Saccone NL, Grucza RA, Wang JC, Cloninger CR, Edenberg HJ, Foroud T, Hesselbrock V, Kramer J, Bucholz KK, Kuperman S, Nurnberger JI Jr, Porjesz B, Schuckit MA, Goate AM, Bierut LJ: Linkage scan for quantitative traits identifies new regions of interest for substance dependence in the Collaborative Study on the Genetics of Alcoholism (COGA) sample. Drug Alcohol Depend 2008, 93:12-20.

99. Lachman HM, Fann CS, Bartzis M, Evgrafov OV, Rosenthal RN, Nunes EV, Miner C, Santana M, Gaffney J, Riddick A, Hsu CL, Knowles JA: Genomewide suggestive linkage of opioid dependence to chromosome 14q. Hum Mol Genet 2007, 16:1327-1334.

100. Bergen AW, Korczak JF, Weissbecker KA, Goldstein AM: A genome-wide search for loci contributing to smoking and alcoholism. Genet Epidemiol 1999, 17(Suppl 1):S55-S60.

101. Swan GE, Hops H, Wilhelmsen KC, Lessov-Schlaggar CN, Cheng LS, Hudmon KS, Amos Cl, Feiler HS, Ring HZ, Andrews JA, Tildesley E, Benowitz N: A genome-wide screen for nicotine dependence susceptibility loci. Am J Med Genet B Neuropsychiatr Genet 2006, 141B:354-360

102. Saccone SF, Pergadia ML, Loukola A, Broms U, Montgomery GW, Wang JC, Agrawal A, Dick DM, Heath AC, Todorov AA, Maunu H, Heikkila K, Morley KI, Rice JP, Todd RD, Kaprio J, Peltonen L, Martin NG, Goate AM, Madden PA: Genetic linkage to chromosome 22q12 for a heavy-smoking quantitative trait in two independent samples. Am J Hum Genet 2007, 80:856-866.

103. Bergen AW, Yang XR, Bai Y, Beerman MB, Goldstein AM, Goldin LR: Genomic regions linked to alcohol consumption in the Framingham Heart Study. BMC Genet 2003, 4(Suppl 1):S101.

104. Crews FT, Boettiger CA: Impulsivity, frontal lobes and risk for addiction. Pharmacol Biochem Behav 2009, 93:237-247.

105. Dom G, Sabbe B, Hulstijn W, van den BW: Substance use disorders and the orbitofrontal cortex: systematic review of behavioural decisionmaking and neuroimaging studies. Br J Psychiatry 2005, 187:209-220.

106. Hill SY, Wang S, Kostelnik B, Carter H, Holmes B, McDermott M, Zezza N, Stiffler S, Keshavan MS: Disruption of orbitofrontal cortex laterality in offspring from multiplex alcohol dependence families. Biol Psychiatry 2009, 65:129-136.

107. De Bellis MD, Narasimhan A, Thatcher DL, Keshavan MS, Soloff P, Clark DB: Prefrontal cortex, thalamus, and cerebellar volumes in adolescents and young adults with adolescent-onset alcohol use disorders and comorbid mental disorders. Alcohol Clin Exp Res 2005, 29:1590-1600.

108. Harris GJ, Jaffin SK, Hodge SM, Kennedy D, Caviness VS, Marinkovic K, Papadimitriou GM, Makris N, Oscar-Berman M: Frontal white matter and cingulum diffusion tensor imaging deficits in alcoholism. Alcohol Clin Exp Res 2008, 32:1001-1013.

\section{Pre-publication history}

The pre-publication history for this paper can be accessed here: http://www. biomedcentral.com/1471-2350/11/43/prepub

doi:10.1186/1471-2350-11-43

Cite this article as: Ehlers et al: EEG alpha phenotypes: linkage analyses and relation to alcohol dependence in an American Indian community study. BMC Medical Genetics 2010 11:43.

\section{Submit your next manuscript to BioMed Central and take full advantage of:}

- Convenient online submission

- Thorough peer review

- No space constraints or color figure charges

- Immediate publication on acceptance

- Inclusion in PubMed, CAS, Scopus and Google Scholar

- Research which is freely available for redistribution

Submit your manuscript at www.biomedcentral.com/submit
Biomed Central 